\title{
THE ARMADA DE BARLOVENTO, FLEET DESPATCH, AND TRANSPORT OF MERCURY TO MEXICO 1637-1738
}

POR

M. F. LANG

Universidad de Salford. Gran Bretaña

\section{IMPORTANCE OF THE ARMADA DE BARLOVENTO}

The importance of the Caribbean flotilla the Armada de Barlovento in trade and transport links between Mexico and Spain in the second half of the XVIIth century is well documented. José de Veitia Linaje discusses its role in an important section of his treatise Norte de la Contratación de Indias (1). The valuable study of the Armada de Barlovento by Bibiano Torres Ramíerez dwells on its deployment, its excursions against piracy, and the problems of its administration and crewing (2). In the present article the intention is rather to trace the close connection between the deployment of this flotilla, the general fleet system, and above all the critical problem of keeping the Mexican silver mines adequately supplied with mercury from Almadén in Spain, a supply which was essential since without mercury the silver could not be refined, there being no supply from within that viceroyalty - unlike Peru which could depend on a local supply from Huancavelica. It should be emphasised here that its was precicely the study of the supply of mercury which repeatedly

SigLAS UTILIZADAS:

AGI: Archivo General de Indias, Sevilla.

AGN: Archivo General de la Nación, México.

(1) José Veitia LinaJe, Norte de la Contratación de las Indias, Estudio preliminar y edición de Francisco de Solano, Madrid, Ministerio de Hacienda, 1981, libro II. cap. v.

(2) Bibiano Torres Ramírez, La Armada de Barlovento, Sevilla, Escuela de Estudios Hispanoamericanos, 1981. Strangely Haring doesn't deal with Barlovento in his study of colonial trade, C. HARING, Comercio y navegación entre España y las Indias, Mexico, Fondo de Cultura 1979. There are frequent reference to Barlovento in L. García FuENTES, El comercio español con América 1650-1700, Sevilla 1980. 
raised for the present author the question of the utilisation of the Armada de Barlovento.

\subsection{Antecedents and Foundation}

The origins of this flotilla, which caused so much concern to the viceroys, as reflected in their Memorias, are said to go back to 1514 when a squadron under Juan Ponce de León was sent against the corsairs already active in the Caribbean. In 1578 there is mention of a similar squadron, and subsequently ad hoc flotillas were formed in the same manner to clear the coasts of Mexico and the Caribbean of piracy and foreign intruders. The components of these flotillas were normally available vessels of the Carrera de Indias which spent the winter in Veracruz awaiting the annual spring return to Spain with the treasure.

In 1636 an attempt was made to institutionalise for the first time the defense of the Caribbean by creating a permanent flotilla under the title of Armada de Barlovento, responding to the reality of the subsequent permanency of piracy and what amounted to settlement of the English and Dutch and French on specific islands and locations on the mainland, whether sanctioned or not by their respective governments. In addition to the defensive role in patrolling the coasts, this squadron was also required to escort the treasure fleets in the crossing from Veracruz to Havana, seeking thereby to prevent the unfortunate loss to pirates or the enemy of the valuable cargoes, as occurred notably in 1628 when the Dutch mariner Piet Heyn caputred the New Spain treasure fleet (3).

\subsection{Funding and composition}

Thus from 1636 the Spanish Crown designated funds, via a $2 \%$ levy on the Mexican Merchands Guild (Consulado), for the creation and maintenance of a permanent squadron, based in Veracruz, and periodic stopovers in Puerto Rico, Santo Domingo, and Havana according to strategic needs at any particular time.

(3) This was the fleet under Juan de Benevides y Bazán, weakened through having suffered losses in a storm on leaving Veracruz. For the attack of Heyn see HARING, [2], 296-298. The next major loss of the New Spain fleet was in 1702 when the fleet under Manuel Velasco, on return to Vigo, was caught by the English and Dutch - yet even then the treasure was saved by sending it inland. 
In fact the Armada de Barlovento was seen as the American counterpart to the Armada del Mar Océano in Spain, whose purpose was to defend the coasts of Spain and escort the fleets on departure and return to the peninsula. But from the very beginning, this flotilla was conceived of as being esentially Mexican, certainly in its deployment and its financing, since the Crown, whose coffers were constantly depleted, insisted on it being funded from whithin that viceroyalty. Thus in 1637 the viceroy Marqués de Cadeyrete sent to Spain the sum of 400.000 pesos collected from the $2 \%$ surcharge for the building of the ships which were to make up the new squadron.

The difficult course of the Armada de Barlovento was signalled early on, because shortly afterwards the Consejo de Indias was complaining of the inappropriate use made of the funds received from New Spain: Your Majesty made use of those funds for other urgent purposes (4). Later the Crown instructed the viceroy to finance from the Mexican viceroyalty exhequer the building of ships in Havana and Santo Domingo, without specifying from which specific account these costs were to come.

The funding for new ships did not come to fruition, and the squadron which finally appeared at the end of the 1630s was a makeshift flotilla composed of units from the Carrera de Indias and the Armada del Mar Océano, so unsatisfactory that the King in March 1640 was complaining of the weakness of its capitana and almiranta which were appointed out of dire necessity the lack of really suitable vessels. At the same time the King was urging the viceroy to seek means to strengthen the newly created squadron (5).

\section{FIRST DEPLOYMENT 1636-1647}

In the early 1640s the need for the Armada de Barlovento became very apparent when the Dutch occupied Curacao and

(4) AGI, Indiferente General, legajo 2557, Junta de Guerra de Indias to King, 25/ag./1637. The same document refers to a contract made in 1636 with admiral Francisco Díaz Pimienta for the building of six galleons in Havana, not realised because the Crown failed to pay of its debts to this official.

(5) AGI, Indiferente General 2557, King to Marqués de Cadyrete, 19/jan/1640. This document also complains of the poor condition of the galleons about to sail for Veracruz under general José Centeno. For further details of dates of departures, high fleet commands, see Guillermo CÉSPEDES DE CASILLO, La avería en el comercio de Indias, Sevilla 1945, although this work does not distinguish between flee and Armada de Barlovento. 
other islands in the Caribbean, while the English and French were about to make major settlements in the area. In 1640 discussions were held to reform Barlovento by using units from the fleet (Galeones) about to leave for Peru that year (6). Indeed Barlovento was reformed in this way, headed by a new galleon of 650 tons, the Porciúncula, built in Cantabria. This squadron sailed to the Indies but returned to Spain in 1642 because the viceroy had refused to finance its masting and rigging. In January of that year the Consejo de Indias complained that it was unaware of the whereabouts of this flotilla, guessing that it was either on its way to Spain or stopping over in Havana (7). In 1643 a galleon of Barlovento was lost off Cape Saint Vincent and in 1644 the new 650 ton capitana, now appointed as capitana for the New Spain fleet of that year, was substituted by a 550 ton vessel from the Armada del Mar Océano (8). At the same time, the Mexican Consulado, whose members funded Barlovento, expressed its anguish at the deterioration of this flotilla and the fact that one of its vessels, the 250 ton galleon San José had a rotting hull (9). In november 1643 a bitter dispute broke out in Cadiz because admiral Antonio de Isasi, in charge of the Armada del Mar Océano, refused to obey an order of the Casa de la Contratación to hand over two galleons to make up the Armada de Barlovento (10).

Nevertheless Barlovento was reformed again by the spring of 1644, consisting of six merchantmen (urcas) and a totalling 2.500 tons. It sailed out with the Veracruz fleet in July of that year. In the Spring of 1645 the fleet general, Martin Carlos de Mencos, requested escorting by Barlovento all the way back to Spain, a request resisted by the viceroy who insisted on the defensive nature of the squadron and its main role in patrolling the New Spain and Caribbean waters. In the event, Martin Carlos de

(6) AGI, Indiferente General 2557, Indies to King, 17/jan/1640. These galleons were really pat of the Armada for Cartagna in the Spring of 1640, which split off at Puerto Rico to pickup the tresure in Veracruz, since the capitana and almirantaof the Mexican fleet were judged to be too weak to bring back the treasure that year.

(7) AGI, Indiferente General, Indias to King, 30/jan/1642.

(8) AGI, Indiferente General 2557, Junta de Guerra de Indias, to King, 19/sept/1643.

(9) AGI, Indiferente General 2557, Indias to King, 23/sept/1643 and 5/oct/1643. In these documents the Consejo de Indias blames the failure to strengthen Barlovento on the resistance of the Junta de Armadas to hand over the necessary vessels.

(10) AGI, Indiferente General 2557, Indias to King, 16/nov/1643. The excuses of Isasi, rejected by the Consejo de Indias, were based on equivalent tonnages. 
Mencos prevailed, and the flotilla returned with the fleet to Spain in 1645, departing again for Veracruz in 1646 after the Casa de la Contratación negotiated loans at $12 \%$ for its careenage in Cadiz (11). Again, the fleet general Juan de Urbina insisted on the return of Barlovento to Spain in 1647.

\subsection{Features of the first deployment}

This first phase of the deployment of the Armada de Barlovento, which had lasted a mere ten years and had been extremely contentious between the authorities in Spain and those in the colonies, ended with its dispersal among the resources of the Armada del Mar Océano and the Carrera de Indias. The positive aspect of this phase was the harmony between the high command of Barlovento and that of the New Spain fleet, even when their departures from Cadiz and Veracruz coincided. This harmony was unusual in an era when personal rivalry and bickering at high command level and below was the was the norm, contrasting with the quarrelsome nature of realtions between fleet commanders and royal authorities ashore. It appears that the regulations were successful in laying down a hierarchy whereby the Barlovento commanders held supreme rank in the VeracruzHavana route, but deferrred to fleet commanders in the transatlantic crossings. No doubt mutual resentment of port authorities served as a common bond betwen commanders of Barlovento and those of the fleet proper.

It is obvious already in this first phase that there was a clear difference between the vessels of Barlovento and the galleons of the Carrera de Indias. Essentially the vessels of the Carrera, albeit armed, were merchantmen designed to carry the largest merchant cargo possible in accordance with their tonnage. Even the two warships that headed the fleet, capitana and almiranta, almost always appointed from units of the Armada del Mar Océano, carried important merchant cargo, namely silver, mercury, iron, tools and equipment, as well as personnel and passengers. Barlovento on the other hand has a purely naval function, with no commercial role, so much so that the regulations strictly forbade this flotilla, albeit in vain, to transport merchan-

(11) AGI, Indiferente General 2557, Indias to King, 27/dez/1645. These loans were to be paid off from the King's treasure from Veracruz or from the silver of the galleons due to return from Cartagena. 
dise or carry out trade of any kind. This prohibiton involved problems of cost, since unlike the Carrera, Barlovento could not be funded through freight licenses and depended on the viceregal funding through the $2 \%$ levy as well as on loans raised in Cadiz and Seville by the Casa de la Contratación. In fact the $2 \%$ levy continued to be raised, even in years when Barlovento was dispersed, and was used by the Crown for whatever purposes it thought fit, and particularly for contracts to build new galleons in Spain, although these contracts were rarely realised. In 1647, for example, 12.000 ducats of the Barlovento fund were assigned to the construction of galleons in San Sebastian for the Armada del Mar Océano (12).

In Cadiz, the authorities reluctantly tolerated the unwelcome arrival of this squadron in the winter months, secquestrating its vessels and equipment for the campaigns in Europe - thus in 1643 two vessles of Barlovento were assigned to the Duke of Ciudad Real for an expedition to Tangiers, and later in 1666 five Barlovento vessels were transferred to the Armada Real (13). It was normal that these units, or the armament and rigging belonging to them, were not returned in time for the summer sailing to Mexico, so that when it returned to Veracruz the Barlovento armada was even more poorly equipped than when it had sailed from the Indies to Spain.

Another way in which the Spanish authorities compensated for the inconvenience of having to look after the Armada de Barlovento when it arrived in Cadiz was to use its capitana to transport to Mexico products on behalf of the King, contravening the regulation that Barlovento whould not carry merchandise. This was imposed by the permanent situation of the lack of suitable vessels to serve as capitana and almiranta of fleets. So the tonnage provided by Barlovento was utilised to transport mercury, in one of two ways; either the Barlovento vessels were used to transport amounts of mercury left over from the main fleet, thus relieving the capitana and almiranta of the fleet which were always overloaded, as occurred for example in 1646 on the fleet of Juan de Urbina, or the capitana of Barlovento was made to serve as capitana for the whole fleet, taking the principal mercury cargo, as was the case in the fleet of Carlos Martin de Mencos in 1644 when the supply of mercury was particularly critical - it was necessary to send that year an amount represen-

(12) García Fuentes, [2], 189.

(13) AGI, Indiferente General 2557, Indias to Casa de la Contratación, 19/9/1643. 
ing two years production in Almadén plus a last minute supply obtained from the Austrian mines of Idria (14).

\section{DISPERSAL $1646-1663$}

In 1646 general Juan de Urbina, having returned with his fleet to Spain, pressed for an increase in the Barlovento flotilla to eight galleons and a total of 3.000 tons. In 1648 the Consejo de Indias reported that the cost of despatching Barlovento from Spain in 1644 and 1646 amounted to 432.530 pesos, raised via loans from the Consulado of Seville. So far the Crown had managed to pay off only half of this debt, while the volume of interest accrued. This lack of funds prevented the despatch of Barlovento with the fleet in June of that year (1648). A further obstacle to the deployment of Barlovento on this occasion, and a shackle on its previous effectiveness, was the bitter opposition to it of the Cadiz customs who viewed it as a front for contraband trade, an attitude based on a good measure of reality.

A further deterent to the reformation of Barlovento was the incapacity of the Peruvian and Mexican fleets to rendez-vous as foreseen in Havana every Spring, the dates being upset by delays and suspension of individual fleets; in fact in the second half of the XVIIth century, the goal of the joint departure from Havana was achieved in barely $30 \%$ of cases. For this reason the authorities resorted to the use of the Armada de Barlovento to escort the returning Mexican fleet out of Havana and across the Atlantic back to Spain, where it wintered and returned to Veracruz with the following year's fleet. These crossings to Spain left the Caribbean coasts defenceless, much to the irritation of the Mexican Merchants Guild (Consulado) which continued to supply the funds for the maintenance of the Barlovento flotilla. Moreover, due to the constant penury of the Crown, both in Spain and in the Indies, the Armada de Barlovento became a financial embarassment both for the viceroys in Mexico, responsible for the cost of its maintenance in Veracruz and the Casa de Contratación in Seville, responsible for its maintenance during its stays in Cadiz. This gave rise to the bitter disputes between Mexico and Spain as to who was ultimately responsable for costs. Thus while the

(14) This was the last batch of mercury obtained from Idria via the contract with Antonio Balbi. See M. F. LANG, El monopolio estatal del mecurio en el México colonial, Fondo de Cultura, Mexico 1977, 124-125. 
authorities in Seville accused the viceroys of seeking excuses to send Barlovento to Spain in order to offload its costs in Veracruz, the Mexican authorities on the other hand felt agrieved at having to finance a squadron which was absent from the Indies during half the year, leaving the Caribbean exposed to pirate and enemy activity.

These problems were very apparent during the first phase of deployment in the 1640 s and where to plague Barlovento during the remander of its precarious existence. It is not surprising that Veitia Linaje states categorically that the disintegration of Barlovento in the period 1646-048 gave rise to a huge increase in piracy in the Caribbean (15).

In 1653 a new atempt was made to reform this flotilla, to be based in Puerto Rico, but again financial problems arose. After the capture of Jamaica by the English in 1655, the authorities in Madrid discussed the possibility of a flotilla of fourteen galleons, on condition that it was never to cross the Atlantic (16).

\section{BARLOVENTO REFORMED 1663-1670}

It was not until 1665 however that Barlovento once again materialised, as a result of the capture of Campeche in 1663 by Manseault and Guiana by the English in 1664. In 1663 the Casa de la Contatación, advised by generals Juan de Urbina and Pablo Fernández de Contreras, had drawn up a report listing the ports and defenses of the Caribbean mainland, emphasising their weak points, and urging the reformation of Barlovento composed of 810200 ton galleons. The report pointed out that the cost of the new squadron, covered in any case by the $2 \%$ levy which had continued to be applied, would be offset by the saving in not having to strengthen weak coastal defences. It was also pointed out that the cost would be modest bearing in mind that Barlovento would patrol a coastline five times longer than that coast of Spain itself (17).

In the event the new Barlovento squadron was composed of six Dutch galleons under the command of the Basque mariner Agustín Dióstegui who financed their purchase in return for his

(15) Veitia Linaje, [1], lib., II, cap. v, no. 4.

(16) AGI, Indiferente General 2517, Pedro de Medrano to Marqués de Mancera, 15/avril/1664.

(17) Veitia Linaje, [1], lib., II, cap. v, no. 5. 
appointment as general, with Alonso de Campos as admiral. This flotilla was to be more active than the 1640s Barlovento in suppresing piracy, illegal trade, and all enemy activity. It was to be based in Puerto Rico and to extend its sphere of action to the south in an atttempt to restrain piracy along the coasts of Nueva Granada and Panamá. The cost of maintenance was calculated at 500.000 pesos per year (18). From this date on, the Armada de Barlovento played an intermittent role in navegation between Spain and the Indies until the naval reforms of 1708 (19).

The concept of the reformed flotilla was that Barlovento would be in Veracruz in the Spring, in time for escorting the treasure fleet to La Habana. There, both fleets would join up with the galleons from Cartagena, and would leave together as far as the Bahamas Canal. There Barlovento would detatch itself, and proceed during the autumn and winter to patrol the islands and coasts, with stopovers at its Puerto Rico base. However, the concept of the Puerto Rico base was quickly abandoned, once again giving preference to Veracruz. This plan of action, together with others elaborated by the Consejo de Indias in the second half of the XVIIth century, in fact was followed only sporadically.

Let us now consider the deployment of the new squadron in 1665, whose total tonnage reached 1.950. Its Dutch components assembled in Santander in the autmn of 1664. In 1665 general Dióstegui was ordered to proceed to Corunna to join the Flanders squadron on its way to the Azores to escort back into Cadiz the mercury ships (azogues) from Veracruz under the command of Francisco Martínez de Granada (20).

Having completed this mission, Dióstegui's squadron was despatched to Valencia to pick up troops based in Aragón and transport them to Cadiz for the campaign against Portugal. However this order was subsequently cancelled and Barlovento was now integrated to the Armada del Mar Océano until the autumn of 1666, patrolling the Atlantic coast of Spain. Thus two and a half years after its creation, the flotilla of Dióstegui had still not crossed the Atlantic let alone accomplished its principal mission of escorting the treasure out of Veracruz and operating against Caribbean piracy. This is the period referred to by Veitia Linaje

(18) Idem, lib II, cap. v, no. 6.

(19) For an account of these reforms, basically financial, see E. PÉrezMaillana Bueno, Política naval española en el Atlántico, Seville 1982, págs. 325329.

(20) AGI, Indiferente General 1792, King to Franciso Martínez de Granada, 14 /avril/ 1664. 
when he speaks of the clamour from the Indies for it (i.e. the Armada de Barlovento) (21).

Meanwhile, in March 1665, the Casa de la Contratación in Seville had rejected the proposal to use part of Dióstegui's squadron to make up the Mexican fleet, describing its vessels as feeble merchantmen (urcas desestimadas) totally inappropriate for transporting the treasure and the mercury (22).

In 1667, the Casa de la Contratación encountered great difficulties in dispatching the Mexican fleet because of the late return of the 1666 fleet under the Conde de Villalcázar. At the same time the viceroy was clamouring for an emergency supply of mercury for the mines. The solution was to make use of Dióstegui's squadron, however inadequate his vessels were. Yet by this time the Armada de Barlovento was in a pitiful state, none of its vessels having been careened during the three years they had served in the Armada del Mar Océano. Thus it had practically to be reformed anew, under the previous capitana and almiranta and adding two new 200 ton galleons, one built in Spain (thereby contravening the old regulation that Andalusian built ships were excluded from the Atlantic crossing). The mercury was loaded on the capitana San Felipe and on the almiranta La Concepción, and the other ships of the squadron were ordered to detach themselves of Puerto Rico to proceed against the pirates. Although this squadron attempted to depart from San Lúcar in June 1667, it was frustrated by the notrious bar and did not depart until July 19th with a cargo of 2.618 quintals of mercury (23).

On arrival in Veracruz, Dióstegui requested 355.545 pesos of the 500.000 assigned, but was given only 100.00 thereby unleashing the usual squabbles over the costs of the wintering in New Spain. In these circumstances Dióstegui decided to bring forward his departure to February 1668 and to return to Spain for provisions and careenage. With the treasure on board, Dióstegui reached Havana in March 1668 and from there despatched the almiranta and other galleons under admiral Alonso Campos to patrol the southern Caribbean. The general returned with his

(21) Veitia Linaje, [1], lib., II, cap. v, no. 9. In this section Veitia Linaje krelates in detail the unfortunate circumstances of the loss of Barlovento udner admiral Alonso Campos.

(22) AGI, Indiferente General 2600, Contratación to Indias, 13/march/1665.

(23) AGI, Indiferente General 2613, Indias to Reina Gobernadora, $15 / \mathrm{may} / 1675$. 
capitana to Spain in January 1669, integrated to the returning Mexican fleet of Gaspar de Argandona (24).

Meanwhile, the Consejo de Indias had been counting on the availability of the Armada de Barlovento to escort out of Veracruz the fleet of Enrique Enriquez Guzmán, due to set sail for Havana in the Spring of 1669. Since by that date Dióstegui was already back in Spain, Enríquez Guzmán decided to delay his departure from Veracruz until Barlovento returned to the Indies. He waited in vain, received no information about the whereabouts of Barlovento, and in late August 1669 set sail unescorted. All these circumstances reflect the great uncertainty and unreliability of the Barlovento squadron when it was required, either to accompany the treasure or to act against piracy, and demonstrate the effect of this uncertainty on the logistics of fleet despatch.

Meanwhile the detachment under admiral Alonso Campos, weakened by the absence of the capitana under Dióstegui, was caught by surprised and destroyed off Marcabibo by the Dutch in the summer of 1668. Campos himself survived this disaster, but was arrested and sent in chains to Spain by the viceroy Marqués de Mancera on the fleet of Gaspar de Argandona in 1669. In short, the only positive result of the reformation of the Armada de Barlovento in 1665 was the safe delivery of the mercuy to New Spain in 1667 and the transport of the treasure to Spain in 1669 (25). The disastrous failure of this squadron on its reappearance in regard to its action against piracy once again led to its dispersal in 1669-70.

\section{REFORMATION AND DEPLOYMENT 1676-1738}

Subsequently various proposals were received in Madrid by Basque mariners proposing to organise a squadron from Corunna or Vigo to act against piracy in the Caribbean, in return for licenses to trade. Although these proposals were seriously considered in the Council of the Indies, they were finally rejected since it was feared that these sailings would have a negative effect on the commercial sucess of the annual fleets, would be

(24) AGI, Indiferente General 2601, Contratación to Indias, 7/1/1670 and TORRES [2], pág. 88.

(25) AGl, Indiferente General 2601, Instructions to Enrique Enriquez Guzmán, March 1668. 
detrimental to the Andalusian trade monopoly, and would obstruct the efficient collection of export and import duties (26).

Given the disembering of Barloventu, the decade of 1670 was a peak era in piracy, with the capture by Morgan of Portobelo and another sacking of Campeche. In reply, the Armada de Barlovento was reformed in 1676, made up of galleons from the Carrera de Indias. Nevertheless this time it consisted only of capitana and almiranta, which sailed out to Veracruz but without the other galleons promised. Later this nucleus was increased to five vessels, all financed theoretically by the Mexican levy. As always, the viceroy was obliged to divert these funds to other urgencies of government, undermining the maintenance and permanency of this squadron. In the late 1670s Barlovento was engaged in lacklustre patrols around the islands of the Caribbean, with long stays in port awaiting supplies, rigging, and finance. As usual, the final destiny of the squadron was to cross the Atlantic to Spain and be integrated to the Armada del Mar Océano (27).

In 1681 it is again identified as a separate squadron, this time used to substitute galleons unavailable for making up the regular fleet. When the fleet of 1680 under Gaspar de Velasco was detained in Veracruz, the Armada de Barlovento was fitted out in Spain under the command of Juan Pereda de Salcedo for the purpose of transporting 1.500 quintals of Almadén mercury urgently needed by the Mexican silver mines. The instructions to Juan Pereda included the task of subsequently clearing the coasts of pirates. The departure of this squadron from Spain, programmed for February 1681 was frustrated by an outbreak of epidemia in Cadiz, so that exceptionally the sailing was transferred to the nearby Puerto Real. There is no clear indication of the progress of this flotilla after reaching Veracruz in May 1681, and it is to be supposed that after the usual patrols through the Caribbean it was integrated to the returning fleet of Diego de Zaldivar in 1683. Once again the most positive aspect of the deployment of Barlovento was the safe delivery of the mercury cargo (28). In 1685 Barlovento was active clearing the Caribbean

(26) For details of the proposals of the Basque mariners see F. SERrano MANGAS, Los galeones en la Carrera de Indias 1650-1700, Sevilla 1985. págs. 120 132. On various occasions towards the end of the XVIIth century the King threatened to authorise Basque commerce with America in order to intimidate the Seville Merchants Guild.

(27) J. Rivera Gambas, Los gobernantes de México, Mexico, Porrúa, 1872. pág. 651 .

(28) AGI, Contratación 4324, no. 2, 226 (libros de carga y dato), and AGN, 19, 75, 149, Conde de Paredes to King, 24.12.1682. 
coasts after the sacking of Campeche, a deployment which delayed the return to Spain of the mercury ships under Martín Garcia Suárez which had to await the return of the Mexican flotilla to its Veracruz base (29).

In this period the gaol seems to have at least partically achieved of retaining Barlovento in the Indies without returning to Spain, although its effictiveness was minimal. In 1687 the Mexican fleet under José Fernandez de Santillana which sailed from Cadiz at the end of June carried equipment and rigging to restore the Barlovento galleons languishing in Veracruz (30).

In 1688 the costs of maintaining Barlovento amounted to 484.659 pesos, matching the 5.000.000 of the annual funding (31). At the beginning of the 1690s Barlovento spent most of its time docked in Havana, since it was feared that the openness of the port of Veracruz exposed it to greater wear and tear (32). In 1691 the Casa de la Contratación urged the need to improve the performnance of this flotilla, recommending an offer by the Sevillian mariner Francisco Garrote to build a galleon in Havana at his own cost, 54 varas long and 18 wide, to strengthen the Barlovento squadron (33). In July 1692, the Armada de Barlovento escorted the fleet out of Veracruz, commanded by the Conde de San Remi, arriving in Havana on August 11 th. Thre it was learned that a French fleet of 131 vessels was lying in wait off the Azores. On September 9th, while escorting the returning fleet to the Bahamas Canal, Barlovento lost its capitana and other galleons in a storn. The rump of the squadron escorted the fleet to Cadiz, sailing out again in July 1693 (34).

At the end of 1697, under general Andrés de Pez and admiral Guillermo Morfi, Barlovento encountered a French squadron off

(29) Barlovento on this occasion was under the command of Antonio de Asturia, financed with 50.000 pesos borrowed from funds of the Havana fort (presidio). AGI, Mexico 354, royal officials of Veracruz to Indias, 12/avril/1686.

(30) These two galleons were for making up the losses of Barlovento in Veracruz. AGI, Indiferente General 2605, Indias to King, 7/july/1687.

(31) This expense, in the accoutns of the fleet which returned to Spain in December 1688, was exceeded only by that of the fortresses (presidios) of the viceroyalty (=714.647 pesos), AGI, Indiferente General 2605, Indias to King, $3 /$ jan/1689.

(32) Rivera [27], 651.

(33) The Casa de la Contratación was strongly in favour of this offer. Garrote asked in return for a license to sdend his galleon San Bernardo with the 1691 fleet, to be scuppered in Veracruz. AGI, Indiferente General 2583, Contratación to King, 9/jan/6691.

(34) AGI, Indiferente General 2584, Conde de San Remi to Consejo de Indias, 4/dez/ 1693. 
the coast of Santo Domingo, leading to the loss of its almiranta and the dispersal of its other components. Subsequently general and admiral were brought to justice in Spain, but Andrés de Pez was later reinstated to head the important 1708 fleet (35).

During the 1690s and the decade of 1700-1710, four factors combined to obstruct the despatch of fleets to the Indies. The War of the spanish Succession, the continued activity of pirates, the weakness of the American market for European products, and the constant lack of all kinds of galleons suitable for the Atlantic crossing. Thus the Casa de la Contratación had to resort to ad hoc solutions to ensure the indispensable supply of mercury and the transport back to Spain of the treasure. One solution was to use limited small scale despatches - the so called mercury galleons (azogues) whose principal cargo was the mercury on leaving Spain and the treasure on the return. The other was the use of the resources of the Armada de Barlovento to make up the lack of regular fleet. Thus, during these two decades there is reference to the use of Barlovento to transport the mercury although it is not always clear whether it was functionaing as an autonomous unit or integrated on an ad hoc basis to full or partial fleets (medias flotas). At the same time, Barlovento was retained for longer periods in the Indies.

In 1701 general Fernando Chacón headed mercury ships with 8.000 quintals of mercury for Veracruz and on return was escorted with the treasure by the Armada de Barlovento under Andrés de Ariola. On the outward voyage the capitana of fleet, San Juan Bautista, carried 220 rolls of canvas for Barlovento rigging. After unloading the mercury, the almiranta Santa María de Tezanos was lost in a storm off Veracruz and the vessels of the Armada de Barlovento were called into service to assist in the salvage operations (36).

In 1702, the viceroy Duke of Albuquerque complained of the deterioration of the Barlovento squadron, emphasising especially the chaotic state of its accounts, the corruption of its officers, the illegal trade in which its crews were involved, and above all its incapacity to sail out of port, remaining in harbour without setting sail, as usually occurs, for most of the time the goals for

(35) In fact Andrés de Pez headed this fleet as general of the Armada de Barlovento. This was the first flet to sail under the new regulations. See PÉREZMaILlaNa [19], págs. 11-12.

(36) AGI, Indiferente General 2731, viceroy to King, 13/avril/1702 and AGI, Indiferente General 2731, Indias to King 19/jul/1701. 
which it was founded are unrealised (37). In 1703, on the occasion of an urgent supply of mercury sent under admiral Francisco Garrote, the King instructed the viceroy Albuquerque to fit out Barlovento to escort Garrote on departure from Veracruz in the autumn of that year, first as far as Havana, and then to the Bahamas Canal. Garrote was to defer to the Barlovento command during this first phase of his return voyage. Barlovento was to detatch itself after escorting Garrote and sail to Puerto Rico, Santa Marta, Cartagena, and the coast of Venezuela to deliver funds for the pay of troppos in the coastal fortresses, pick up equipment for Mexico and return to Veracruz. When Garrote left Veracruz eventually in January 1704 he qas escorted by Barlovento, composed of six galleons. However, strong winds from the north dispersed the Barlovento galleons, detatching them from the main flotilla, and when the admiral reached Havana he was escorted by only one vessel, the Barlovento almiranta. Later, giving testimony in Cadiz, Garrote expressed disgust at the nautical competnece of his Barlovento escort (38).

Hence throughout this period Barlovento continued to be deployed, but in a sporadic faction, with a minimum of effectiveness, with its crew and equipment diverted ad hoc to other uses. However it functioned seldom as an autonomous unit, serving as an escort or being integrated into the convoys or partial fleets. Its role in transporting or safeguarding the transport of mercury was in fact its greatest achievement. In 1706, 1708, and 1711, one again Barlovewnto was deployed to transport the essential ingredient of the silver mining refining process (patio).

Its role in the subsequent decades of the XVIII th century was feebler still, because from 1708 the fleet system was rationalised and reformed while piracy diminished and greater tolerance was shown in the acceptance of foreign intrusion. The mercury supply was entrusted increasingly to the azogue galleons, now established as a regular system. The decreasing importance of Barlovento ended in its suppression in 1738 when a royal decree described it as a monster in expense and a micky mouse (hormiga) in its effectiveness (39).

(37) AGI, Indiferente General 2737, viceroy to King, 15/may/1702. The viceroy complained moreover of the frauds committed by the generals of Barlovento with regard to provisions during their stays in the port.

(38) AGI, Indiferente General 2733, Francisco Garrote to King, 22/avril/1704.

(39) TORREs [2], pág. 212. 


\section{CONCLUSIONS}

Summing up, it is evident that in the polital and naval history of the Spanish Empire, the Armada de Barlovento is usually dismissed as a feeble and ineffictive flotilla. Of course it failed in its principal objective of suppressing piracy and enemy incursions in the Caribbena, and it was strikingly prone to losses through strom and attack. At the same time there has been a tendency to think of it a a permanent fixed entity, a subsidiary of the Carrera de Indias and the Armada del Mar Océano, the Caribbean cosunterpart of the Armada del Mar del Sur which served the coast of Perú. In fact, although in theory it was conceived of as such, in practice it was essentially an expeditionary force, always improvised according to the urgencies of the moment. Moreover it is clear from the details of the individual deployments described above, that although it was initially conceived of as a Mexican flotilla, in practice it was important in the Atlantic crossing in general, and sailed as often out of Cadiz as out of Veracruz. In its favour it may be pointed out that however unsatisfactory its deployment may have been, languishing as it did in port through lack of finance, in fact no New Spain treasure fleet was lost to piracy or the enemy after its foundation and that the occasional losses of fleet galleons were due rather to storms. It may well be that awareness of its very existence and the mystery surrounding its whereabouts and deployment at any one time acted as a deterrant restraining possible attacks on the treasure fleets, and limiting pirate sucesses to the coastal settlements. If this is taken into consideration together with its valueable role in delivering mercury at critical times, and in safely escorting the treasure fleet to Havana, and frequently across the Atlantic back to Spain as well then it has to be recognised that this flotilla was not as useless as is sometimes thought, and indeed that its deployment was relatively acceptable bearing in mind that the Crown constantly deprived it of funds. Further, it is apparent from the details of the deployment of Barlovento in the years of its active existence that the theoretical division of naval forces between Carrera de Indias, Armada del Mar Océano, Armada de Barlovento, and other squadrons, was a purely artificial one, since vessels and equipment were constantly interchanged between all 
these flotillas. Finally, it must be empasised again that the idea of Barlovento as a purely American flotilla is not borne out be the facts, that in judging its performance its European and Atlantic performance must be taken into consideration, and that in the last analysis the only purely Hispanic American squadron was the Armada del Mar del Sur which was deployed along the Pacific coast of South America. 